\title{
Transarticular invasion of primary bone tumors abutting the sacroiliac joint: an MRI study in 128 patients
}

\section{Lei Ding}

Sun Yat-sen University First Affiliated Hospital

Junqiang Yin

Sun Yat-sen University First Affiliated Hospital

Fangling Zhang

Sun Yat-sen University First Affiliated Hospital and Hospital of Stomatology

\section{Yongqian Wang}

Sun Yat-sen University First Affiliated Hospital

\section{Changye Zou}

Sun Yat-sen University First Affiliated Hospital

\section{Zhen-hua Gao ( $\nabla$ Gzhh_sysu@163.com )}

Sun Yat-sen University First Affiliated Hospital

\section{Research article}

Keywords: sacroiliac joint, bone tumors, transarticular invasion, MRI

Posted Date: February 27th, 2020

DOI: https://doi.org/10.21203/rs.2.24763/v1

License: (9) (i) This work is licensed under a Creative Commons Attribution 4.0 International License. Read Full License 


\section{Abstract}

Background: To investigate magnetic resonance imaging (MRI) manifestation of transarticular invasion of primary bone tumors abutting the sacroiliac joint.

Methods: We conducted a retrospective analysis of MRI data in 128 patients from January 2004 to December 2015. The diagnosis confirmed by surgical findings and pathological examination. The tumors of 87 patients located in the ilium and 41 patients in the sacrum. Tumors were divided into high-grade (Group 1), low-grade (Group 2) malignant tumor group and intermediate tumor group (Group 3). Transarticular invasion routes included 3 types: across ligament (Type 1), across articular cartilage (Type 2) and across periarticular tissue (Type 3 ).

Results : Transarticular invasion were observed in 33 patients (25.8\%): Group 1 (22 patients) included 15 patients (51.7\%) with conventional osteosarcoma and 7 patients (43.8\%) with Ewing's sarcoma; Group 2(5 patients) included 4 patients $(11.4 \%)$ with central chondrosarcoma and 1 patient $(7.7 \%)$ with chordoma; Group 3(6 patients) included 4 patients (20.0\%) with giant cell tumor of bone, 1 patient (16.7\%) with chondroblastoma and 1 patient $(11.1 \%)$ with aneurysmal bone cyst. The difference of transarticular invasion incidence was not significant statistically between primary iliac and sacral tumors $(P>0.05)$. The differences were significant statistically between group 2 and group 1, group 3 and group 1 , respectively $(P<0.01)$. Significant differences were observed among different invasion types $(P<$ 0.01): type 1(31 times), type 2(15 times) and type 3(5 times).

Conclusions: MRI is sensitive and useful to evaluate transarticular invasion of primary bone tumors abutting the sacroiliac joint.

\section{Background}

Due to the deep location of primary bone tumors abutting the sacroiliac joint, the tumors may invade the sacroiliac joint or even cross it at the time of diagnosis. Preoperative accurate diagnosis of transarticular invasion of the sacral or iliac tumor plays an important role in the design of surgical program ${ }^{[1]}$. Imaging studies of pelvic bone tumors invading the sacroiliac joint have been rarely reported in the literature ${ }^{[1-4]}$. Review of literature on bone tumor invasion of the sacroiliac joint raises several questions for further study: (1) The accuracy of MRI in the diagnosis of sacroiliac joint invasion by tumor. (2) The sacroiliac joint includes the anterior-inferior synovial joint and posterior-superior ligamentous portion. Are the transarticular invasion incidences or invasion types similar between ilium-originated and sacrumoriginated tumors? (3) The differences of the transarticular invasion incidences and invasion types among different pathological types or different grades of tumors. Therefore, this study was aimed at evaluating the value of MRI in detecting transarticular invasion of primary bone tumors abutting the sacroiliac joint based on the above questions.

\section{Methods}




\section{Patients}

Clinical and MRI data of 128 patients treated in our hospital from January 2004 to December 2015 were collected. Diagnosis was confirmed by surgical findings and pathological examination. There were 80 men and 48 women with an average age of 32.5 years (range: $4-74$ years). The primary tumors of 87 patients were originally located in the ilium and 41 patients in the sacrum. 29 patients were diagnosed with conventional osteosarcoma, 16 with Ewing's sarcoma, 35 with central chondrosarcoma (grade II), 13 with chordoma, 20 with giant cell tumor of the bone ( 6 of which were complicated with secondary aneurysmal bone cyst), 6 with chondroblastoma and 9 with primary aneurysmal bone cyst. Based on pathology grading systems, these tumors were divided into the high-grade malignant tumor group (Group 1, 45 patients with conventional osteosarcoma or Ewing's sarcoma), the low-grade malignant tumor group (Group 2, 48 patients with central chondrosarcoma or chordoma) and the intermediate tumors group (Group 3, 35 patients with giant cell tumor of the bone, chondroblastoma or aneurysmal bone cyst).

\section{Examination method}

All the patients underwent a Siemens Magnetom Vision 1.5 T or Magnetom Trio Tim 3.0T whole-body superconducting MRI scanners (Germany). The MRI sequence included a T1-weighted conventional spin echo sequence ( $T R=450-600 \mathrm{~ms}, T E=12-14 \mathrm{~ms})$, T2-weighted fast spin echo sequence ( $T R=3000-$ $4500 \mathrm{~ms}, \mathrm{TE}=90-120 \mathrm{~ms}$ ), $\mathrm{T} 2 \mathrm{Wl}$ with fat suppression ( $\mathrm{TR}=3000-4500 \mathrm{~ms}, \mathrm{TE}=90-120 \mathrm{~ms}$ ), enhanced T1WI (TR $=450-600 \mathrm{~ms}, \mathrm{TE}=12-14 \mathrm{~ms})$, and enhanced $\mathrm{T} 1 \mathrm{Wl}$ with fat suppression $(T R=450-600 \mathrm{~ms}$, $T E=12-14 \mathrm{~ms}$ ). Gadolinium-diethylenetriamine pentaacetic acid (Gd-DTPA) at a concentration of $0.5 \mathrm{mmol} / \mathrm{L}$ was intravenously administered at a dose of $0.2 \mathrm{ml} / \mathrm{kg}$ and at a rate of $1.0 \mathrm{ml} / \mathrm{s}$ for enhanced scans. The slice thickness was $5-8 \mathrm{~mm}$, and the interlayer spacing was $0.5-0.8 \mathrm{~mm}$.

\section{Imaging evaluation}

Sacral or iliac tumors with minimum length less than $2 \mathrm{~cm}$ from the tumor margin to the ipsilateral sacroiliac joint surface was defined as bone tumors abutting the sacroiliac joint ${ }^{[4]}$. The transarticular invasion was defined as sacral/iliac tumor invaded to the contralateral bone of the sacroiliac joint to cause bone destruction ${ }^{[1-4]}$. The MRI images were reviewed by 2 radiologists specializing in bone tumor and the final diagnosis was reached a consensus. The types of transarticular invasion of a bone tumor abutting the sacroiliac joint include (1) transarticular invasion via the ligament located at the posteriorsuperior part of the sacroiliac joint (i.e., invasion across the ligamentous potion) (Type 1, Fig. 1); (2) transarticular invasion via direct destruction of the cartilage located at the anterior-inferior part of the sacroiliac joint, across the articular space (i.e., invasion across the articular cartilage) (type 2, Fig. 2); and (3) transarticular invasion across the muscles and ligaments around the sacroiliac joint (i.e., invasion across the periarticular tissue) (type 3, Fig. 3). For tumors in which 2 or more types coexisted (including invasion across the entire sacroiliac joint, i.e., Type $1+$ Type 2; invasion across the entire joint and periarticular tissues, i.e., Type 1 + Type 2 + Type 3), each type was separately counted once (Fig. 4). 


\section{Statistical analysis}

SPSS 17.0 statistical software was used for data analysis. The chi-squared test for count data was used to compare the differences of the transarticular invasion incidences and types among different locations, different pathological types and different pathological grades of primary bone tumors. A P value less than 0.05 was considered statistically significant.

\section{Results}

\section{MRI diagnostic accuracy}

Bone tumors abutting the sacroiliac joint can cause bone destruction and show abnormal MRI signal. The tumor tissue can invade into the sacroiliac joint or spread along the surrounding structures to the contralateral bone of the joint, resulting bone destruction and replacement with tumor tissue meanwhile. In this study, 33 of $128(25.8 \%)$ patients presented with transarticular invasion (Table 1), which was 100\% consistent with the surgical findings and pathological examination.

\section{Comparison of transarticular invasion incidences in different locations}

Of the 128 patients, 87 patients were diagnosed as iliac tumors, with $26(29.9 \%)$ patients presenting with transarticular invasion; 41 patients had sacral tumors, with $7(17.1 \%)$ patients presenting with transarticular invasion (Table 1). In general, the incidences between the iliac and sacral primary tumors were not different statistically $(\chi 2$ value $=2.39, P>0.05)$. The difference of transarticular invasion incidence was not compared in Group 1 because their proportions were not compatible (43 iliac tumors and 2 sacral tumors). No statistically significant difference was observed in Group $2 \varangle 26$ iliac tumors and 22 sacral tumors, $\chi 2$ value $=0.04, P>0.05 \llbracket$ and Group $3 \bowtie 18$ iliac tumors and 17 sacral tumors $₫ \chi 2$ value $=$ $0.14, P>0.05 \rrbracket$.

\section{Comparison of the transarticular invasion incidences in different pathological grades}

The overall difference of transarticular invasion incidences were significant statistically among different pathological grades $(\chi 2$ value $=19.84, P<0.01)$. There were significant differences in Group 1 and Group2, Group 1 and Group 3 respectively $(P<0.01)$ (Table 2), but no difference between Group 2 and Group 3 statistically $(\chi 2$ value $=0.32, P>0.05)$.

\section{Comparison of the transarticular invasion incidences in different pathological types}

The overall transarticular invasion incidence of malignant bone tumors (Group $1+$ Group 2) was 29.0\% (27/93). The transarticular invasion incidences were high in the patients with conventional osteosarcoma $(51.7 \%)$ and those with Ewing's sarcoma (43.8\%), but low in the patients with central chondrosarcoma $(11.4 \%)$ and those with chordoma (7.7\%) (Table 1). The overall incidence of transarticular invasion was $17.1 \%(6 / 35)$ in intermediate bone tumors (Group 3) and the differences were not statistically significant 
among the 3 sub-types (giant cell tumor, chondroblastoma and aneurysmal bone cyst) ( $\chi 2$ value $=0.25, P$ $>0.05)$.

\section{Comparison of transarticular invasion types}

The details of transarticular invasion type were shown in Table 3. Type 1 and type $1+$ type 2 were common, whereas type 2 and type 3 were rare. Table 4 was the number of individual invasion type in the 33 patients. The overall transarticular invasion incidences were different among type 1, type 2 and type 3 $(\chi 2$ value $=41.74, P<0.01)$. Further pairwise comparison showed statistic differences among the three types ( $\chi 2$ values and corresponding $P$ values were as follows: $\chi 2$ value $=18.37, P<0.01 ; \chi 2$ value $=41.31$, $P<0.01 ; \chi 2$ value $=7.17, P<0.01)$. Transarticular invasion across the ligamentous portion was the most common type, followed by the articular cartilage type and finally, the periarticular tissue type. The incidences of type1/ type2/ type3 were not significantly different $(P>0.05)$ among the three groups respectively.

\section{Discussion}

Among the imaging techniques (X-ray, CT, MRI, SPECT and PET/CT) assessing the bone tumors, MRI has its unique advantage to show the intramedullary, surrounding soft tissue, adjacent joint invasion and bone metastasis. Abnormal signal changes on MRI can not only clearly reveal the location, size and range of bone tumors abutting the sacroiliac joint but also show the destruction of the cortex and invasion of the contralateral bone via different structures. According to the literature, the sensitivity and specificity of MRI were $100 \%$ and $92 \%$ respectively if a strict definition of transarticular invasion was used $^{[2,4]}$. In this study, 33 of 128 patients with primary tumors abutting the sacroiliac joint presented with transarticular invasion on MRI images and confirmed by surgical findings and pathological examination, corresponding with the literature. MRI can detect transarticular invasion with high sensitivity and accuracy. The iliac cartilage was thinner compared with the sacral cartilage, which is an anatomical characteristic of the sacroiliac joint. Although transarticular invasion incidence was higher in the iliac tumor than in the sacral tumor ( $29.9 \%$ vs. $17.1 \%)$, this difference was not statistically significant. 27 of 93 (29.0\%) patients with malignant bone tumors(Group 1 and 2)were diagnosed with transarticular invasion. Of 35 patients with intermediate bone tumors (Group 3), only 6 patients $(17.1 \%)$ presented with transarticular invasion, including 4 patients with giant cell tumor of bone, 1 patient with chondroblastoma and 1 patient with aneurysmal bone cyst. These results indicated that intermediate bone tumors are somewhat aggressive but the transarticular invasion incidence was significantly lower than that of malignant bone tumors. In conclusion, the invasion incidence was not associated with anatomical characteristic of the sacroiliac joint but associated with the malignant degree.

In our study, the incidence of transarticular invasion was highest in Group 1 (conventional osteosarcoma $(51.7 \%)$ and Ewing's sarcoma (43.8\%)), but was low in Group 2(central chondrosarcoma (11.4\%) and chordoma $(7.7 \%))$. The incidence of osteosarcoma was similar to the results reported in the literature ${ }^{[2,4]}$. Nevertheless, the incidences of chondrosarcoma and Ewing's sarcoma were obviously different from that 
in the literature. Ozaki et al. reported in two different studies ${ }^{[2,4]}$ that the transarticular invasion incidence of chondrosarcoma was $47.1 \%$ and $46.7 \%$ respectively, for Ewing's sarcoma was $4.3 \%$ and $8.7 \%$ respectively. We did not compared the results with other studies related to this because their sample sizes were too small ${ }^{[5-7]}$. These discrepancies may be attributed to differences in inclusion criteria. Firstly, Ozaki's study only included patients with the primary iliac tumor, whereas our study included patients with both primary iliac and sacral tumors. Secondly, minimum length of tumor margin away from the joint surface less than $2 \mathrm{~cm}$ was not an inclusion criteria in Ozaki's study ${ }^{[2]}$. Next, patients with highgrade chondrosarcoma accounted for $80 \%$ of all patients with chondrosarcoma in the studies by Ozaki ${ }^{[2,}$ 4], whereas patients with low-grade chondrosarcoma (well-differentiated central chondrosarcoma) were predominant in our study. For chondrosarcoma, the degree of malignancy may be a main reason for the transarticular invasion. The transarticular incidence of chordoma has not been reported in the literature and the incidence of it was only $7.7 \%$ in our study. This may be associated with its low-grade malignancy and less invasive nature. In addition, chordoma is usually located at the midline of the lower sacrum ${ }^{[8]}$, which is distant from the sacroiliac joint relatively.

Of the 33 patients with tumor invasion across the sacroiliac joint, a few patients showed involvement of two or more invasion types. The statistical results showed differences in incidences among the 3 types: type 1 was the most common type, followed by type 2 and then, type 3 . In addition, the incidences of different types were not associated with the malignant degree of tumors. Isolated invasion across the articular cartilage was very rare, so Type 2 was usually accompanied by type 1 , indicating that the cartilage may prevent the joint to be invaded by the tumor to some degree. These findings were consistent with that in the previous literature ${ }^{[2,4]}$. The prevention mechanism of cartilage may be related to the following factors: $\otimes$ There are no blood vessels in the articular cartilage. Thus, a direct anatomical channel and blood supply for tumor growth are lacking ${ }^{[8]}$. $\otimes$ Cartilage cells can produce a substance to inhibit tumor angiogenesis ${ }^{[9]}$ and collagenase activity ${ }^{[10-12]}$.

\section{Conclusions}

In summary, MRI can accurately diagnose transarticular invasion of primary bone tumors abutting the sacroiliac joint. The transarticular invasion incidence is associated with pathological type, benignity or malignancy, and the malignant degree of a tumor rather than its location (sacrum or ilium). The invasion type $o$ is not related to the malignant degree of a tumor. Transarticular invasion across the ligamentous portion is quite common. The cartilage portion may be a barrier against tumor invasion, but as the tumor grows the cartilage can be destroyed and subsequently cause transarticular invasion.

\section{Abbreviations}

MRI

magnetic resonance imaging

Gd-DTPA 
Gadolinium-diethylenetriamine pentaacetic acid

CT

computerized tomography

SPECT

single photon emission computed tomography

PET

positron emission tomography

\section{Declarations}

\section{Ethics Approval and Consent to Participate}

The current study was approved by the Institutional Ethics Committee of the First Affiliated Hospital of Sun Yat-Sen University, and the need for signed informed consent was waived.

\section{Consent for Publication}

We have obtained consent to publish from all the participants.

\section{Availability of data and materials}

The datasets used and analysed during the current study are available from the corresponding author on reasonable request.

\section{Competing interests}

The authors declared that they have no conflict of interest. No authors have received any funding from any institution, including personal relationships, interests, grants, employment, affiliations, patents, inventions, honoraria, consultancies, royalties, stock options/ownership, or expert testimony for the last 12 months.

\section{Funding}

This work was supported by the Medical Scientific Research Foundation of Guangdong Province, China \No: B2010073区. Funding supporter played no role in the design of the study and collection, analysis, and interpretation of data and in writing the manuscript.

\section{Authors' Contributions}

LD and JQY participated in design of the study, collected the patients' data, and drafted the manuscript. FLZ, YQW, CYZ processed the figures, helped draft the manuscript, and performed critical revision of the manuscript. ZHG conceived and designed the study, supervised the project. All authors read and approved the final version of the manuscript. 
Acknowledgements

Not applicable.

\section{References}

[1] Chhaya S, White LM, Kandel R, Wunder JS, Ferguson P, Agur A. Transarticular invasion of bone tumours across the sacroiliac joint. Skeletal Radiol. 2005. 34(12): 771-7.

[2] Ozaki T, Lindner N, Hillmann A, Link T, Winkelmann W. Transarticular invasion of iliopelvic sarcomas into the sacrum. Radiological analysis of 47 cases. Acta Orthop Scand. 1997. 68(4): 381-3.

[3] Abdelwahab IF, Miller TT, Hermann G, Klein MJ, Kenan S, Lewis MM. Transarticular invasion of joints by bone tumors: hypothesis. Skeletal Radiol. 1991. 20(4): 279-83.

[4] Ozaki T, Rodl R, Gosheger G, et al. Sacral infiltration in pelvic sarcomas: joint infiltration analysis II. Clin Orthop Relat Res. 2003. (407): 152-8.

[5] Drnovsek V, Zafiroski G, Brogdon BG, Plavsic BM. Transarticular spread of Ewing's sarcoma across the sacroiliac joint: CT and MRI correlation. Orthopedics. 1999. 22(10): 977-9.

[6] Jordanov MI, Block JJ, Gonzalez AL, Green NE. Transarticular spread of Ewing sarcoma mimicking septic arthritis. Pediatr Radiol. 2009. 39(4): 381-4.

[7] Chong VF, Pathmanathan R, Sambandan SS. Transarticular spread of the sacroiliac joint in a chondrosarcoma. Med J Malaysia. 1994. 49(3): 282-4.

[8] Simon MA, Hecht JD. Invasion of joints by primary bone sarcomas in adults. Cancer. 1982. 50(8): 1649-55.

[9] Quan GM, Ojaimi J, Nadesapillai AP, Zhou H, Choong PF. Resistance of epiphyseal cartilage to invasion by osteosarcoma is likely to be due to expression of antiangiogenic factors. Pathobiology. 2002. 70(6): 361-7.

[10] Kuettner KE, Pauli BU, Soble L. Morphological studies on the resistance of cartilage to invasion by osteosarcoma cells in vitro and in vivo. Cancer Res. 1978. 38(2): 277-87.

[11] Sorgente N, Kuettner KE, Soble LW, Eisenstein R. The resistance of certain tissues to invasion. II. Evidence for extractable factors in cartilage which inhibit invasion by vascularized mesenchyme. Lab Invest. 1975. 32(2): 217-22.

[12] Eisenstein R, Kuettner KE, Neapolitan C, Soble LW, Sorgente N. The resistance of certain tissues to invasion. III. Cartilage extracts inhibit the growth of fibroblasts and endothelial cells in culture. Am J Pathol. 1975. 81(2): 337-48. 


\section{Tables}

Table 1 Transarticular invasion incidences of 128 patients with primary bone tumors abutting the sacroiliac joint

\begin{tabular}{cccc}
\hline Tumor type & $\begin{array}{c}\text { Total number } \\
\text { of patients } \\
\text { (Ilium/sacrum) }\end{array}$ & $\begin{array}{c}\text { Number of patients with } \\
\text { transarticular invasion } \\
\text { (Ilium/sacrum) }\end{array}$ & $\begin{array}{c}\text { Transarticular } \\
\text { invasion } \\
\text { incidence (\%) }\end{array}$ \\
\hline $\begin{array}{c}\text { Conventional } \\
\text { Osteosarcoma } \\
\text { Ewing's sarcoma }\end{array}$ & $29(27 / 2)$ & $15(13 / 2)$ & 51.7 \\
$\begin{array}{c}\text { Central } \\
\text { chondrosarcoma } \\
\text { Chordoma }\end{array}$ & $35(26 / 9)$ & $7(7 / 0)$ & 43.8 \\
$\begin{array}{c}\text { Giant cell tumor } \\
\text { of the bone }\end{array}$ & $20(8 / 12)$ & $4(2 / 2)$ & 11.4 \\
Chondroblastoma & $6(4 / 2)$ & $1(0 / 1)$ & 7.7 \\
Aneurysmal bone & $9(6 / 3)$ & $1(1 / 0)$ & 16.7 \\
cyst & $128(87 / 41)$ & $1(1 / 0)$ & 11.1 \\
Total & $33(26 / 7)$ & \\
\hline
\end{tabular}

Table 2 Comparison of transarticular invasion incidences among different pathological grades

\begin{tabular}{|c|c|c|c|c|c|}
\hline $\begin{array}{l}\text { Patient } \\
\text { group }\end{array}$ & $\begin{array}{l}\text { Total } \\
\text { number of } \\
\text { patients }\end{array}$ & $\begin{array}{c}\text { Number of patients } \\
\text { with transarticular } \\
\text { invasion }\end{array}$ & $\begin{array}{l}\text { Transarticular } \\
\text { invasion incidence } \\
(\%)\end{array}$ & $\begin{array}{l}\chi^{2} \text { value } \\
\text { between the } \\
\text { groups }\end{array}$ & $\begin{array}{l}P \text { - } \\
\text { value }\end{array}$ \\
\hline Group & 45 & 22 & 48.9 & Group vs. $]$ & प \\
\hline 1 & & & & 16.68 & 0.01 \\
\hline Group & 48 & 5 & 10.4 & Group $\square$ vs. & ૫ \\
\hline 2 & & & & 0.32 & 0.05 \\
\hline Group & 35 & 6 & 17.14 & Group $\square$ vs. $]$ & 口 \\
\hline 3 & & & & 8.72 & 0.01 \\
\hline
\end{tabular}


Table 3 Transarticular invasion types of 33 patients (cases)

\begin{tabular}{|c|c|c|c|c|c|c|}
\hline Tumor type & $\begin{array}{l}\text { Across } \\
\text { the } \\
\text { ligament } \\
\text { portion } \\
\text { Type1 }\end{array}$ & $\begin{array}{c}\text { Across } \\
\text { the } \\
\text { articular } \\
\text { cartilage } \\
\text { Type2 }\end{array}$ & $\begin{array}{l}\text { Across the } \\
\text { whole joint }\end{array}$ & $\begin{array}{l}\text { Across the } \\
\text { periarticular } \\
\text { tissue } \\
\text { Type3 }\end{array}$ & $\begin{array}{c}\text { Across the } \\
\text { whole joint } \\
\text { and } \\
\text { periarticular } \\
\text { tissue }\end{array}$ & Total \\
\hline & & & & & $\begin{array}{c}\text { Type1+Type2 } \\
\text { +Туре3 }\end{array}$ & \\
\hline $\begin{array}{l}\text { 'onventional } \\
\text { steosarcoma }\end{array}$ & 6 & 0 & 5 & 0 & 4 & 15 \\
\hline ing's sarcoma & 4 & 1 & 2 & 0 & 0 & 7 \\
\hline $\begin{array}{c}\text { Central } \\
\text { sndrosarcoma }\end{array}$ & 3 & 0 & 1 & 0 & 0 & 4 \\
\hline Chordoma & 0 & 0 & 0 & 1 & 0 & 1 \\
\hline $\begin{array}{l}\text { ant cell tumor } \\
\text { of the bone }\end{array}$ & 2 & 0 & 2 & 0 & 0 & 4 \\
\hline ndroblastoma & 1 & 0 & 0 & 0 & 0 & 1 \\
\hline $\begin{array}{l}\text { eurysmal bone } \\
\text { cyst }\end{array}$ & 0 & 0 & 0 & 0 & 1 & 1 \\
\hline Total & 16 & 1 & 10 & 1 & 5 & 33 \\
\hline
\end{tabular}

Table 4 Number of individual transarticular invasion type in 33 patients (times) 


\begin{tabular}{ccccc}
\hline & Tumor type & (Type 1) & (Type 2) & (Type 3) \\
\hline Group 1 & Conventional osteosarcoma & $100 \%(15 / 15)$ & $60 \%(9 / 15)$ & $26.7 \%(4 / 15)$ \\
& Ewing's sarcoma & $85.7 \%(6 / 7)$ & $42.9 \%(3 / 7)$ & $0(0 / 7)$ \\
Group 2 & Central chondrosarcoma & $100 \%(4 / 4)$ & $25 \%(1 / 4)$ & $0(0 / 4)$ \\
& Chordoma & $0(0 / 1)$ & $0(0 / 1)$ & $100 \%(1 / 1)$ \\
Group 3 3 & Giant cell tumor of the bone & $100 \%(4 / 4)$ & $25 \%(1 / 4)$ & $0(0 / 4)$ \\
& Chondroblastoma & $100 \%(1 / 1)$ & $0(0 / 1)$ & $0(0 / 1)$ \\
& Aneurysmal bone cyst & $100 \%(1 / 1)$ & $100 \%(1 / 1)$ & $0(0 / 1)$ \\
Total & & $93.9 \%(31 / 33)$ & $45.5 \%(15 / 33)$ & $15.2 \%(5 / 33)$ \\
\hline
\end{tabular}

\section{Figures}

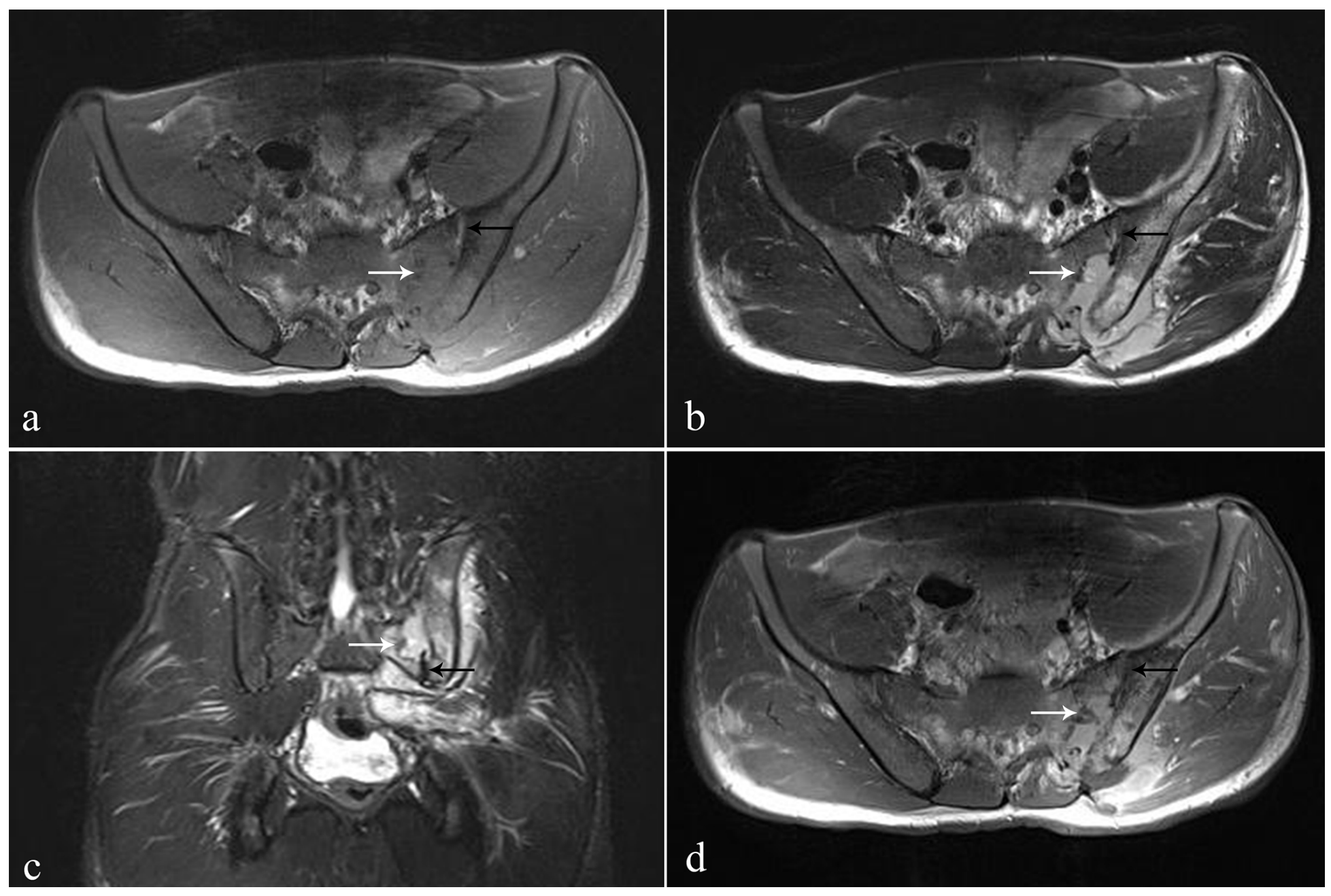

\section{Figure 1}

An 18-year-old boy with left iliac Ewing's sarcoma, presenting transarticular invasion across the ligamentous portion, which was confirmed by surgical findings. MR T1WI (a), T2WI (b), T2WI with fat 
suppression (c), and enhanced T1WI (d) showed bone destruction of the sacrum (white arrow) , the posterior space of the sacroiliac joint and the left portion of the sacrum were filled with tumor tissue with intermediate signal intensity on T1WI and high signal intensity on T2WI. Tumor signals were not observed in the anterior-inferior space (cartilage portion) of the sacroiliac joint (black arrow).

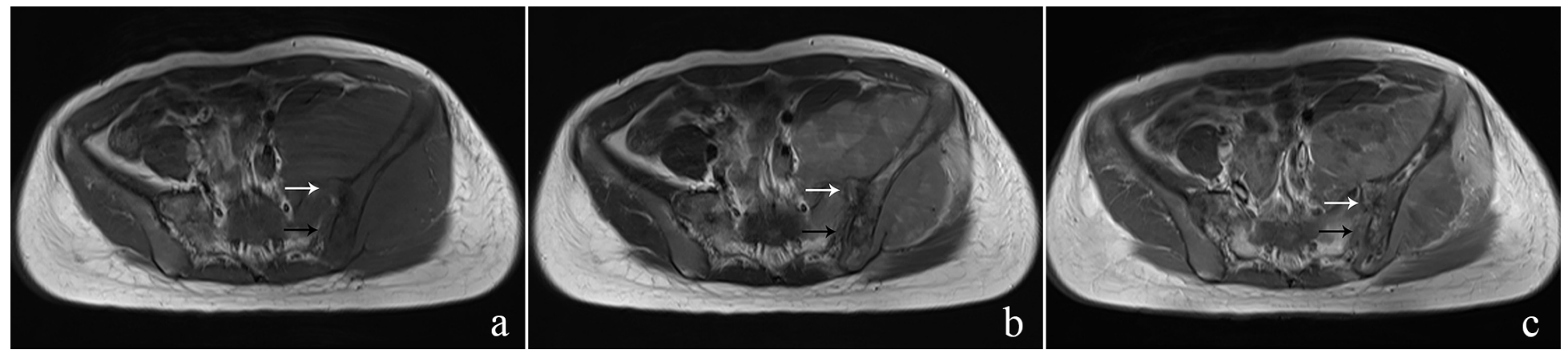

Figure 2

A 15-year-old girl with left iliac Ewing's sarcoma, presenting transarticular invasion to the sacrum across the articular cartilage, which was confirmed by surgical findings. MR T1WI (a), T2WI (b), and enhanced T1WI (c) showed tumor invasion of the sacroiliac joint across the anterior portion of the joint and the articular surface of sacrum was destroyed (white arrow). Tumor signal was also observed in the posterior joint space (ligamentous portion), but the sacral cortical exhibited normal (black arrow).
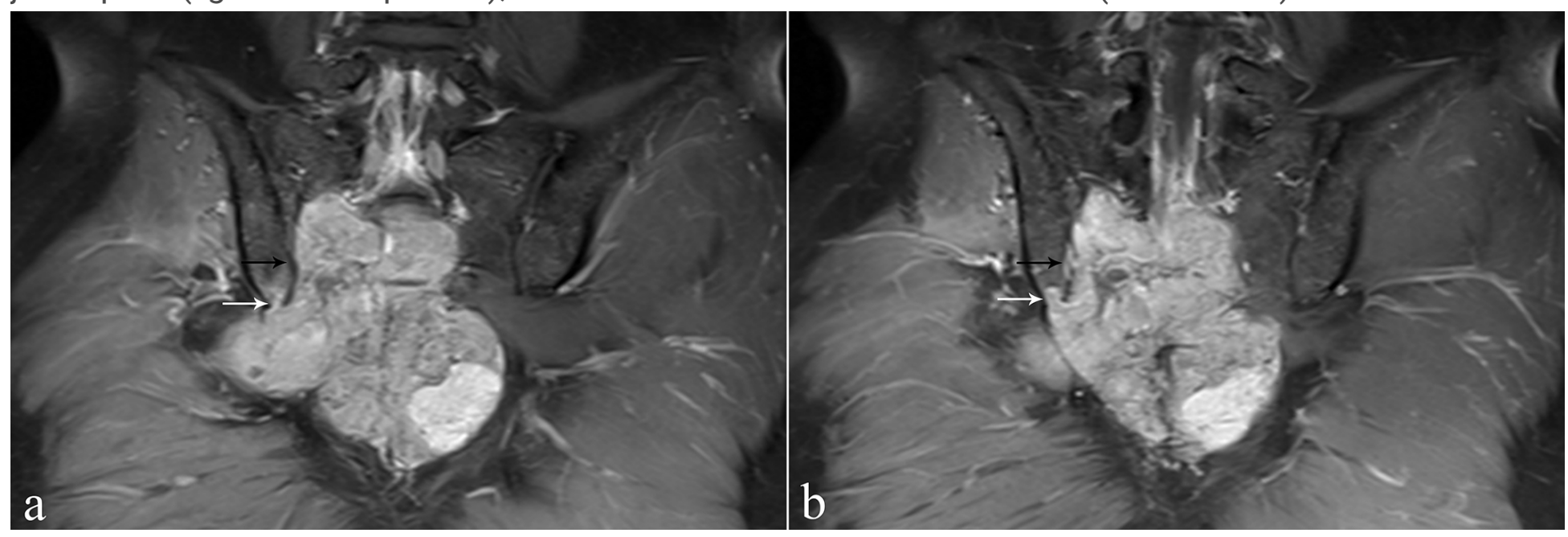

\section{Figure 3}

A 38-year-old male with sacral chordoma, presenting transarticular invasion to the ilium across the periarticular tissue, which was confirmed by surgical findings. MR enhanced T1WI $(a, b)$ showed tumor invasion of the right ilium across the inferior portion of the sacroiliac joint (white arrow), and the articular surface of sacrum was interrupted. But the cortical bone of the right ilium was intact (black arrow). 


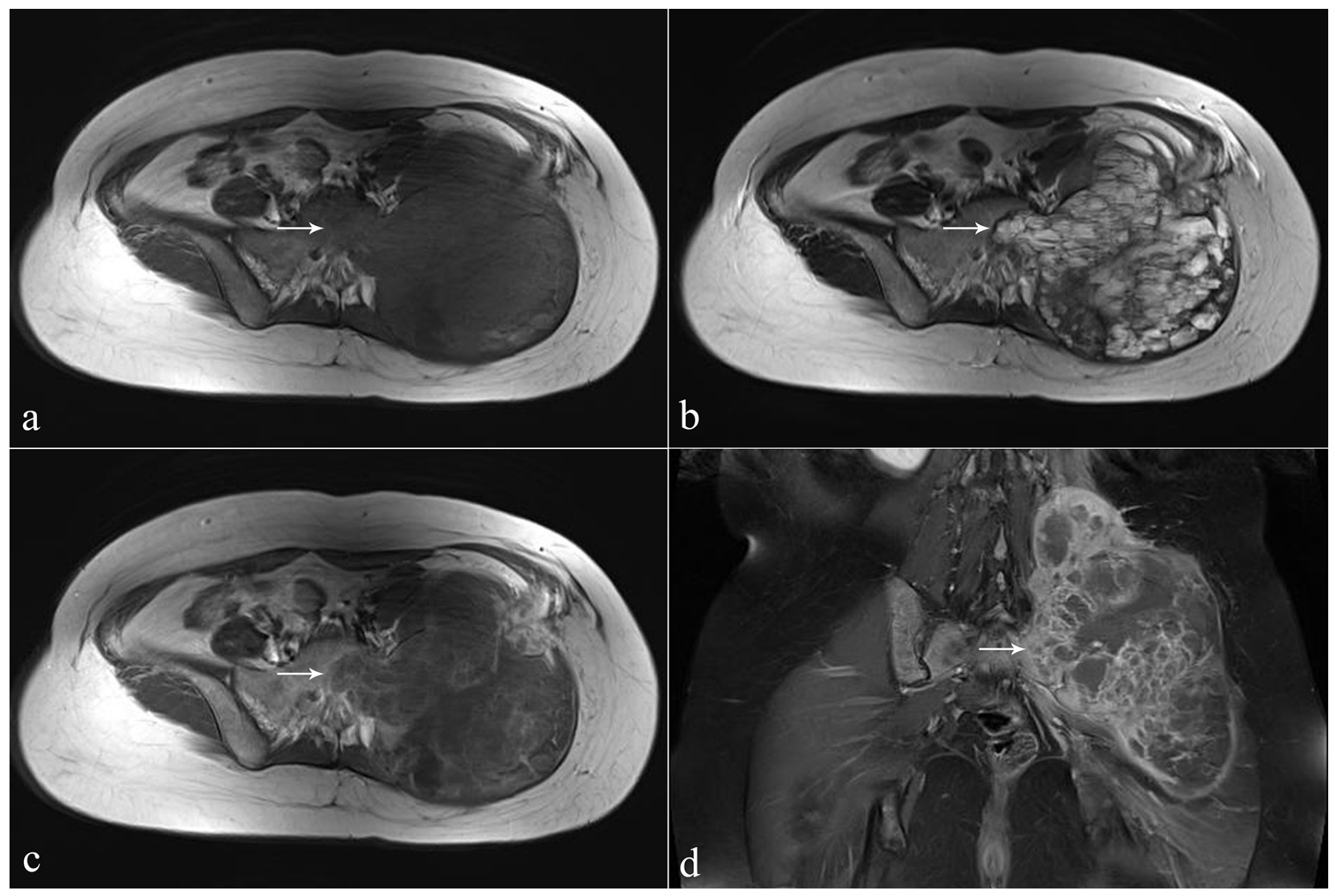

\section{Figure 4}

A 36-year-old female with giant bone cell tumor of the left ilium combined with an aneurysmal bone cyst, presenting invasion of the sacrum across the whole sacroiliac joint (including cartilage and ligamentous portions), which was confirmed by surgical findings. MR T1WI (a), T2WI (b), enhanced T1WI (c), and enhanced T1WI with fat suppression (d) showed tumor invasion of the sacrum across the whole left sacroiliac joint (white arrow). 